
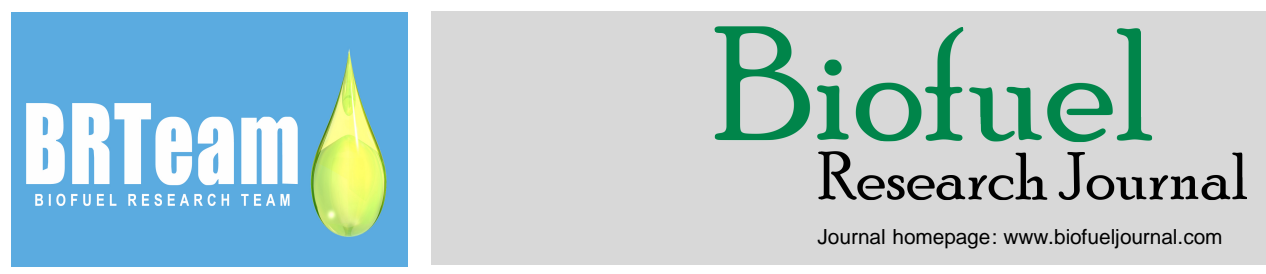

Journal homepage: www.biofueljournal.com

Original Research Paper

\title{
Fermentative biohydrogen production from a novel combination of vermicompost as inoculum and mild heat-pretreated fruit and vegetable waste
}

\author{
María J. Pascualone ${ }^{1, *}$, Marcos B. Gómez Costa ${ }^{2,3}$, Pablo R. Dalmasso ${ }^{1,3, *}$
}

${ }^{1}$ Centro de Investigación y Transferencia en Ingeniería Química Ambiental (CIQA), Facultad Regional Córdoba, Universidad Tecnológica Nacional, Maestro López esq. Cruz Roja Argentina, 5016 Córdoba, Argentina.

${ }^{2}$ Centro de Investigación en Nanociencia y Nanotecnología (NANOTEC), Facultad Regional Córdoba, Universidad Tecnológica Nacional, Maestro López esq . Cruz Roja Argentina, 5016 Córdoba, Argentina.

${ }^{3}$ Consejo Nacional de Investigaciones Científicas y Técnicas (CONICET), Godoy Cruz 2290, C1425FQB Buenos Aires, Argentina.

\section{HIGHLIGHTS}

$>$ Fruit and vegetable waste can be used as low-cost substrate for biohydrogen production.

$>$ Vermicompost was used as novel source of hydrogen-producing bacteria.

$>$ Use of mild heat-pretreated FVW substrate markedly enhanced biohydrogen yield.

$>$ Clostridium species were the dominant

$>$ Biohydrogen production through FVW valorization using the developed process was found promising. microorganisms in the bioprocess

\section{GRAPHICAL ABSTRACT}

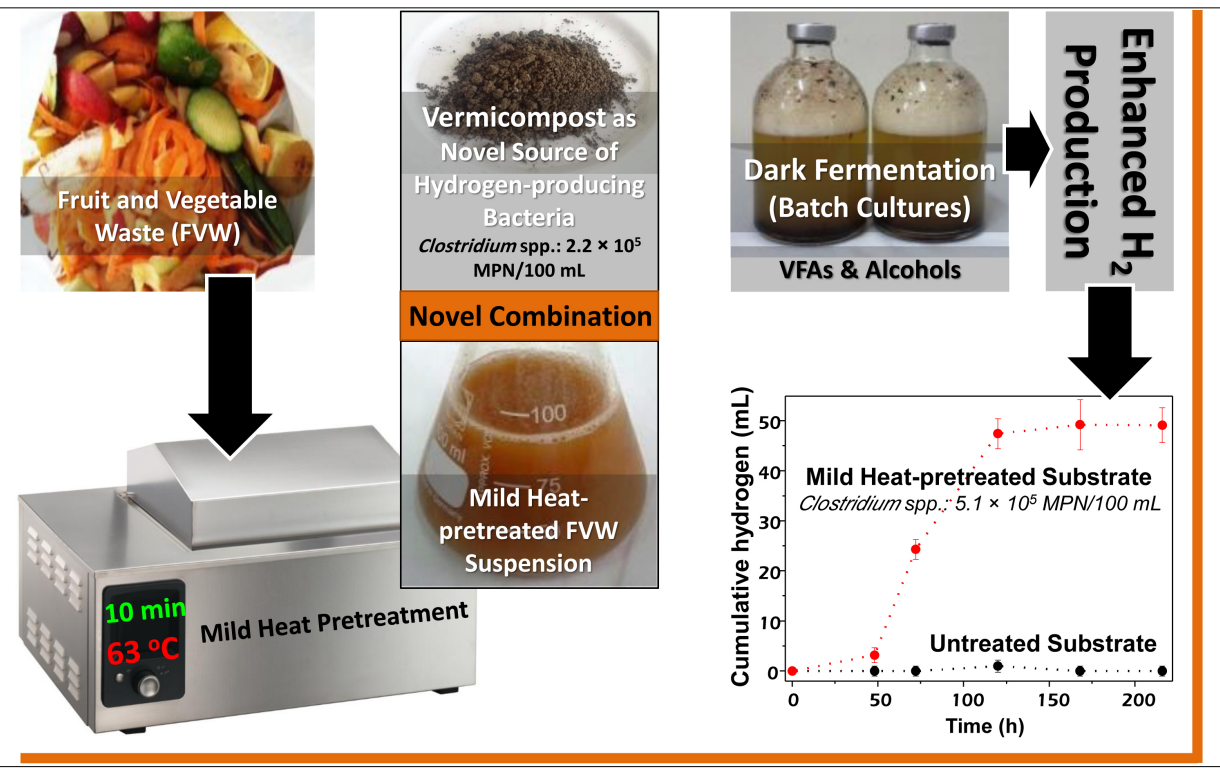

\section{ARTICLE INFO}

\begin{abstract}
This study reports for the first time on biohydrogen production by dark fermentation using a novel combination of mild heatpretreated fruit and vegetable waste (FVW) as raw material and vermicompost as an economical source of hydrogen-producing bacteria. A suspension rich in reducing sugars obtained from FVW was used at different initial concentrations ( 5 to $25 \mathrm{~g}$ reducing sugars/L) during the bioprocess conducted in batch reactors at mesophilic temperature of $35^{\circ} \mathrm{C}$. The use of a mild heat-pretreated substrate and the consequent elimination of the natural microbiota present in the FVW led to higher hydrogen production than the control. Clostridium species, hydrogen-producing bacteria via butyric acid fermentation pathway, were the dominant microorganisms in the bioprocess. Hydrogen production, volumetric hydrogen production rate, and pretreated substrate degradation efficiency $\left(63.0 \mathrm{~mL} / \mathrm{g} \mathrm{VS}, 372.6 \mathrm{~mL} / \mathrm{L} / \mathrm{d}\right.$, and $50 \% \mathrm{BOD}_{5}$, respectively) obtained in the experiments performed with the highest substrate concentration demonstrated that the developed bioprocess was promising simultaneously leading to high hydrogen contents in biogas and high substrate removal efficiencies.
\end{abstract}

(c) 2019 BRTeam. All rights reserved. 


\section{Introduction}

The current challenges of global warming and climate change on one hand and atmospheric pollution resulting from increasing fossil fuels consumption on the other hand are the main driving forces behind the research on alternative energy carriers (Emodi et al., 2019). A very appealing course of action is the application of biological processes to the production of fuels (Hallenbeck and Ghosh, 2009). Hydrogen appears as one of the best alternatives for two reasons: i) the only by-product of its combustion is water (Ghimire et al., 2015), and ii) its energy content per unit mass is the highest, reaching $122 \mathrm{~kJ} / \mathrm{g}$, a value approximately 2.75 times higher than that of conventional hydrocarbon fuels (Elbeshbishy et al., 2017).

While steam reforming of natural gas is the dominant hydrogen production process and is still associated with extensive consumption of fossil fuels (Xia et al., 2016), the biological production route has emerged as one of the most vigorous research areas in the field of hydrogen production (Cai and Wang, 2016). It has the advantages of reducing greenhouse gas emissions by $57-73 \%$, and the ability to run on a cheap and less energy intensive technology (Arimi et al., 2015).

Among the biohydrogen production processes, dark fermentation seems to be a favorable process due to its simplicity, minor energy requirements, higher hydrogen production rates, and the use of waste as raw material (Cui and Shen, 2012). Hydrogen, carbon dioxide, and volatile fatty acids (VFA) are produced during the acidogenesis phase of carbohydrate-rich organic wastes degradation by anaerobic fermentative bacteria (Keskin et al., 2018).

The seed microorganisms used as inoculum and their pretreatment represent a key factor for hydrogen fermentation. In comparison with pure cultures, mixed microbial ones are more commonly used because of their low cost, easiness in control, high versatility, and broader choice of substrate ( $\mathrm{Li}$ and Fang, 2007; Braguglia et al., 2018). Species of the genera Clostridium, Enterobacter, and Bacillus have been frequently isolated from mixed cultures and are responsible for biohydrogen production during dark fermentation (Bundhoo et al., 2015; Rafieenia et al., 2018). Moreover, these bacterial consortia, capable of producing hydrogen, are widely present in natural habitat such as sludge, compost, soil, sediments, leachate, and organic wastes (Wang and Yin, 2017). In order to enrich mixed microbial inoculums for dark fermentative hydrogen production, the inhibition of hydrogen-consuming microorganisms, namely hydrogenotrophic methanogens, is one of the main steps. To achieve that, inoculum pretreatment is carried out through which biohydrogen-producing bacteria can survive when exposed to harsh environmental conditions such as $\mathrm{pH}$ and temperature, due to their ability to form spores (Saady, 2013; Rafieenia et al., 2018).

Given the fact that natural materials can be potential sources for enriching hydrogen producers (Wang and Yin, 2017), new inoculum sources are being proposed, including the use of vermicompost (Oceguera-Contreras et al., 2019). Vermicomposting is a low-cost bio-oxidative process of organic matters facilitated by microorganisms and earthworms, mainly the Californian red earthworm (Eisenia fetida), which yields a biofertilizer popularly known as vermicompost (Domínguez et al., 2010; Gómez-Brandón and Domínguez, 2014). The passage of the organic material through the earthworm favors the existence of an active microbial population, with abundance of bacteria belonging to the Clostridium genus, in the egested material (Hong et al., 2011; Blomström et al., 2016). Therefore, vermicompost is a valuable and economical product as natural source of biohydrogen-producing bacteria.

New sources of cost effective substrate need to be investigated and evaluated according to their potential for biohydrogen production (Ghimire et al., 2015). Food waste constitutes the most representative fraction of municipal solid waste and is also the main factor responsible its methane emissions and landfill leachates (Algapani et al., 2016). Globally, around 2 billion tons of municipal solid waste are formed annually, of which $34-53 \%$ is biodegradable organic waste, mainly food waste collected from households and restaurants, but the composition may vary from country to country (Braguglia et al., 2018). Up to a third of the food produced worldwide for human consumption is spoiled or squandered before its consumption. In this scenario, fruit and vegetable have the highest loss rate, i.e., between 40 to 50\% (FAO, 2011). Therefore, fruit and vegetable waste (FVW) has a great potential for biohydrogen production due to its organic composition and biodegradable nature (Venkata Mohan et al., 2009; Tawfik et al., 2015). Moreover, FVW meets the main criteria considered for the selection of waste for biohydrogen production, i.e., availability and cost, carbohydrate content, and biodegradability (Eker and Sarp, 2017).
The pretreatment methods of organic waste play a significant role in increasing the availability of the substrate (Salem et al., 2018). Among the known methods, heat-based pretreatments for biogas/biohydrogen production seem to be good options resulting in improved digestatability. These pretreatments have been extensively applied in solubilizing lignocellulosic biomasses and enhancing their enzymatic hydrolysis in order to improve the rate and degree of their degradation, thus increasing gas generation (Bundhoo et al., 2015; Braguglia et al., 2018; Wang and Yin, 2018). Microwave-based pretreatment has also been considered as an appealing alternative method owing to its lower energy requirements. However, the results obtained have not been completely satisfactory because despite an increased solubility of organic matter, biogas production was low $(<10 \%)$ (Braguglia et al., 2018). Moreover, pretreatments at temperatures as high as $175^{\circ} \mathrm{C}$ reportedly led to the formation of refractory compounds (melanoidins) inhibiting biogas generation (Shahriari et al. 2012; Braguglia et al., 2018). Mechanical pretreatments, e.g., ultrasounds at $20 \mathrm{kHz}$, exclude the risk of inhibitory compounds formation, but they require high energy consumption (electricity). Enzymatic pretreatments intensify the hydrolytic activity and require much less energy inputs than the mechanical and heat-based methods. However, cost, enzyme selectivity (lipase or glucoamylase), and process efficiency remain as major challenges. Chemical pretreatments with strong acids, alkalis or oxidants, achieve availability levels much higher with respect to those obtained with the other pretreatments, but the risk of chemical contamination and formation of recalcitrant compounds should be considered. Moreover, chemical pretreatments are not suitable for easily biodegradable substrates such as FVW (Braguglia et al., 2018). To the best of our knowledge, there are no reports in the published literature correlating the effect of mild heat pretreatment of FVW on both i) biohydrogen production, and ii) microbial community. Moreover, studies using vermicompost as a source of hydrogen-producing bacteria have not yet been fully explored. There is only one recent work performed by Oceguera-Contreras et al. (2019) using E. fetida lixiviated earthworm and agro-industrial waste as inoculum and substrate, respectively.

Hence, the present study was set to investigate the potential of biohydrogen production by dark fermentation combining a suspension rich in reducing sugars obtained from mild heat-pretreated FVW and heat shock treated vermicompost as inoculum. The influence of the heat pretreatment of the substrate and the initial concentration of reducing sugars on the production of biohydrogen and soluble metabolites, as well as on substrate degradation, were studied by using fermentation batch experiments.

\section{Materials and Methods}

\subsection{Inoculum}

A mixed bacterial culture from a commercial vermicompost (Terrafertil, Argentina) enriched by heat shock was used in the experiments The inoculum was diluted with distilled water to obtain a concentration range of volatile suspended solids (VSS) from 10 to $100 \mathrm{~g} / \mathrm{L}$ and was pretreated to eliminate methanogenic microorganisms in favor of hydrogen-producing populations such as Clostridium species. Given the fact the highest $\mathrm{H}_{2}$ yield was achieved using $25 \mathrm{~g} / \mathrm{L}$, this concentration was selected for the dark fermentation process to produce biohydrogen. The pretreatment consisted of submerging the inoculum in a water bath at 100 ${ }^{\circ} \mathrm{C}$ for $15 \mathrm{~min}$ and then incubating it at $35{ }^{\circ} \mathrm{C}$ for $24 \mathrm{~h}$ (Rafieenia et al., 2018). The heat shock pretreatment was chosen because it is a fast, highly efficient, and simple process (Bakonyi et al., 2014).

\subsection{Fruit and vegetable waste suspension}

The FVW used herein included a wide variety of fruit and vegetable, i.e., bananas, apples, pears, pineapples, melons, kiwis, mandarin oranges, lemons, tomatoes, potatoes, eggplants, cucumbers, cabbages, squash, carrots, radishes, and zucchinis. The waste was grinded using a $2 \mathrm{~L}$ household food grinder with distilled water (ratio 1:1 w/v) for $3 \mathrm{~min}$ at top speed. Solids were separated using both sieves in different sizes and a 400 micron filter cloth (nylon/polyamide knit filter). The filtered suspension obtained from FVW was pretreated in a water bath at $63{ }^{\circ} \mathrm{C}$ for $30 \mathrm{~min}$ to eliminate the microbiota contained in the substrate, which could have 
otherwise competed with the inoculated microorganisms. The resulting suspension was used as substrate in the biohydrogen production.

\subsection{Reaction system}

The experiments on dark fermentative hydrogen production were conducted using batch cultures in $120 \mathrm{~mL}$ serum bottles with $80 \mathrm{~mL}$ of culture broth. The bottles were hermetically sealed with rubber corks and metallic caps. First, they were gassed for $60 \mathrm{~s}$ with nitrogen to achieve anaerobic conditions. Each bottle containing $72 \mathrm{~mL}$ of the filtered suspension obtained from the $\mathrm{FVW}$ at $35{ }^{\circ} \mathrm{C}$ was inoculated with $8 \mathrm{~mL}$ of enriched inoculum ( $2.5 \mathrm{~g} \mathrm{VSS} / \mathrm{L})$. Before loading, the suspension was adjusted to a $\mathrm{pH} 5.5$ with $\mathrm{NaOH} 1 \mathrm{M}$. The process was repeated using different dilutions of mild heat-pretreated and untreated substrate and distilled water. The purpose was obtaining reactants with reducing sugars concentrations of $5,10,15,20$, and $25 \mathrm{~g} / \mathrm{L}$ with a biodegradable organic charge ranging between 4.5 and $22.7 \mathrm{~g} \mathrm{BOD}_{5} / \mathrm{L}$. All trials were carried out at least in triplicate.

\subsection{Analysis}

The volume of biogas production was measured by plunger displacement method (Owen et al., 1979) using $60 \mathrm{~mL}$ syringes equipped with $20 \mathrm{~mm}$ needles. The biogas composition $\left(\mathrm{H}_{2}, \mathrm{CO}_{2}\right.$, and $\left.\mathrm{CH}_{4}\right)$ was determined by a gas chromatograph (Hewlett-Packard 5890 Series II Plus) equipped with a thermal conductivity detector (TCD) and a $30 \mathrm{~m}$ long HP-PLOT/Q capillary column. The oven temperature was set at $60{ }^{\circ} \mathrm{C}$ for $3 \mathrm{~min}$ and was then increased at 15 ${ }^{\circ} \mathrm{C} / \mathrm{min}$ until it reached $250{ }^{\circ} \mathrm{C}$. The injector temperature was $200{ }^{\circ} \mathrm{C}$ and that of the detector was $260{ }^{\circ} \mathrm{C}$. The carrier gas used was He. To determine the concentration of VFA and other organic compounds with low-molecular weight in liquid phase, headspace (HS) was used as sample preparation technique and the subsequent analysis of the gas phase was performed by using a gas chromatograph mass spectrometer (GC/MS) (Thermo Scientific Trace 1310) (Cruwys et al., 2002). A $60 \mathrm{~m}$ long TG-5SILMS capillary column was used, which operated at $35^{\circ} \mathrm{C}$ for $4 \mathrm{~min}, 4^{\circ} \mathrm{C} / \mathrm{min}$ until $60^{\circ} \mathrm{C}$, and $10^{\circ} \mathrm{C} / \mathrm{min}$ until $150{ }^{\circ} \mathrm{C}$. The injector and the ion source both reached a temperature of 200 ${ }^{\circ} \mathrm{C}$. The transfer line temperature was $250^{\circ} \mathrm{C}$. The HS technique was performed placing $10 \mathrm{~mL}$ of the sample in a glass headspace vial; then the vial was sealed and heated at $60{ }^{\circ} \mathrm{C}$ for $30 \mathrm{~min}$ in an oven with automatic temperature controller. The concentration of reducing sugars was measured using the DNS colorimetric method (Miller, 1959). The $\mathrm{pH}$ (Method 4500- $\left.\mathrm{H}^{+} \mathrm{B}\right)$, total solids (TS) (Method 2540 B), volatile solids (VS) (Method 2540 E), VSS (Method $2540 \mathrm{D})$, biochemical oxygen demand $\left(\mathrm{BOD}_{5}\right)$ (Method $\left.5210 \mathrm{~B}\right)$, and chemical oxygen demand (COD) (Method $5220 \mathrm{D})$ were determined according to the Standard Methods (APHA, 2012).

For the quantification of microorganisms associated with the Clostridium spp. genus, the most probable number (MPN) method of sulphite-reducing anaerobes described by the international standard ISO 6461/1-1986 was followed (ISO, 1986) was employed. Microorganisms of the Enterobacter spp. genus were determined by the multiple-tube fermentation technique for members of the coliform group (Method 9221 B) (APHA, 2012).

\subsection{Kinetic model}

The modified Gompertz equation (Eq. 1) has been widely used to describe the progress of the cumulative hydrogen production from a batch experiment (Wang and Yin, 2017):

$H=H_{\text {max }} \cdot \exp \left\{-\exp \left[\frac{R_{\max } \cdot e}{H_{\max }} \cdot(\lambda-t)+1\right]\right\}$

where $\mathrm{H}(\mathrm{mL})$ is the cumulative biohydrogen production in the incubation period $\mathrm{t}(\mathrm{h}), \mathrm{H}_{\max }(\mathrm{mL})$ is the maximum amount of hydrogen produced, $\mathrm{R}_{\max }$ $(\mathrm{mL} / \mathrm{h})$ is the maximum hydrogen production rate, "e" is 2.718 , and $\lambda(\mathrm{h})$ is the lag period (Bo et al., 2012). $H_{\max }, R_{\max }$, and $\lambda$ values for each batch were determined by adjusting the biohydrogen production data by Equation 1 with a nonlinear least-squares regression and minimizing with the LevenbergMarquardt method. The biohydrogen production potential $(\mathrm{mL} / \mathrm{L})$ and the volumetric hydrogen production rate (VHPR, $\mathrm{mL} / \mathrm{L} / \mathrm{d}$ ) were calculated based on $\mathrm{H}_{\max }$ and $\mathrm{R}_{\max }$ per working volume $(80 \mathrm{~mL})$, respectively. Hydrogen yield ( $\mathrm{mL} \mathrm{H}_{2} / \mathrm{g} \mathrm{VS}$ ) was calculated by dividing $\mathrm{H}_{\max }$ per the added VS.

\section{Results and Discussion}

\subsection{Feedstock characterization}

The characteristics of the filtered FVW suspension used as substrate are listed in Table 1. The approximately $1900 \mathrm{~g}$ of FVW used in the experiment yielded $2000 \mathrm{~mL}$ of filtered suspension containing $26.5 \mathrm{~g}$ reducing sugars/L. According to the $\mathrm{BOD}_{5} / \mathrm{COD}$ ratio, about $70 \%$ of the organic matter was biodegradable (Cruz-Salomón et al., 2017; Keskin et al., 2018), The organic content (in terms of VS/TS) indicated high viability of biological treatment (Salem et al., 2018).

Table 1.

Characteristics of the filtered suspension obtained from fruit and vegetable waste (FVW)

\begin{tabular}{ll}
\hline Parameter & Value \\
\hline VS/TS $(\%)$ & $87 \pm 4$ \\
$\mathrm{BOD}_{5}\left(\mathrm{~g} \mathrm{O}_{2} / \mathrm{L}\right)$ & $24 \pm 2$ \\
$\mathrm{COD}\left(\mathrm{g} \mathrm{O}_{2} / \mathrm{L}\right)$ & $33 \pm 2$ \\
Reducing sugars $(\mathrm{g} / \mathrm{L})$ & $26.5 \pm 0.5$ \\
$\mathrm{pH}$ & $4.2 \pm 0.1$ \\
\hline
\end{tabular}

\subsection{Biohydrogen production}

All the conducted experiments produced methane-free biogas containing $\mathrm{H}_{2} \quad(21-46 \%)$ and $\mathrm{CO}_{2}(54-79 \%)$. This confirmed the absence of methanogenic organisms and revealed the efficiency of the heat shock pretreatment of the inoculum (Bundhoo et al., 2015; Rafieenia et al., 2018).

Figure 1 displays the temporal variation of cumulative hydrogen volume for different substrate concentrations $(5-25 \mathrm{~g}$ reducing sugars/L) under untreated and mild heat pretreatment conditions. It can be observed that the cumulative volume increased for a certain period of time and remained constant afterward, reaching its maximum value after $120 \mathrm{~h}$ using the mild heat-pretreated substrate with $25 \mathrm{~g}$ reducing sugars/L

All the experimental data presented in Figure 1 on hydrogen gas production highly correlated with the modified Gompertz equation with correlation coefficients $>0.97$. Table 2 summarizes the parameters obtained in the dark fermentative processes with different concentrations of FVW substrate conducted using either mild heat-pretreated or untreated substrate.

The volumetric hydrogen production in dark fermentation batch reactors using untreated substrate increased with the increment of initial content of reducing sugars from 5 to $15 \mathrm{~g} / \mathrm{L}$ and decreased until it completely ceased with increasing concentrations from 20 to $25 \mathrm{~g} / \mathrm{L}$. The highest value was $300 \mathrm{~mL} / \mathrm{L}$ with $30 \% \mathrm{v} / \mathrm{v}$ of hydrogen in the biogas at $15 \mathrm{~g}$ reducing sugars/L. The propagation of natural microbiota in the untreated substrate (see Section 3.4) and the acidification observed during the experiments (as indicated by the decrease in $\mathrm{pH}$ value from 5.5 to 4 ), must have inhibited the hydrogen-producing bacteria (Lin et al., 2007), resulting in the drop in hydrogen production. Regarding to the mild heat-pretreated substrate, the hydrogen content in the gas phase and the volumetric hydrogen production increased in response to the increments in initial reducing sugars content. The highest values (i.e., $46 \% \mathrm{v} / \mathrm{v}$ and $615 \mathrm{~mL} / \mathrm{L}$ ) were achieved when the highest concentration of substrate was tested. Compared with the untreated substrate, the peak value of volumetric hydrogen production doubled with the mild heat-pretreated substrate.

The data tabulated in Table 2 reveal the advantage of applying the mild heat pretreatment on FVW substrate. More specifically, the Gompertz kinetic parameters for the batch experiments using the mild heat-pretreated substrate were higher than those obtained for the dark fermentation batch conducted with the untreated substrate. Moreover, it can be observed that i) the trend for the $R_{\max }$ values was similar to that of the $H_{\max }$ values, increasing by rising substrate concentration, and ii) the highest values of the $\mathrm{H}_{\max }$ and the $\mathrm{R}_{\max }$ were obtained at $25 \mathrm{~g} / \mathrm{L}(49.2 \mathrm{~mL}$ and $1.2 \mathrm{~mL} / \mathrm{h}$ respectively). The difference in the lag period $(\lambda)$ using mild heat pretreated and untreated substrate ( $47 \mathrm{~h}$ and $36 \mathrm{~h}$, respectively) could be attributed to the fact that the natural microbiota contained in the mild heatpretreated substrate was eliminated (see Section 3.4) and the hydrogen- 
(A)

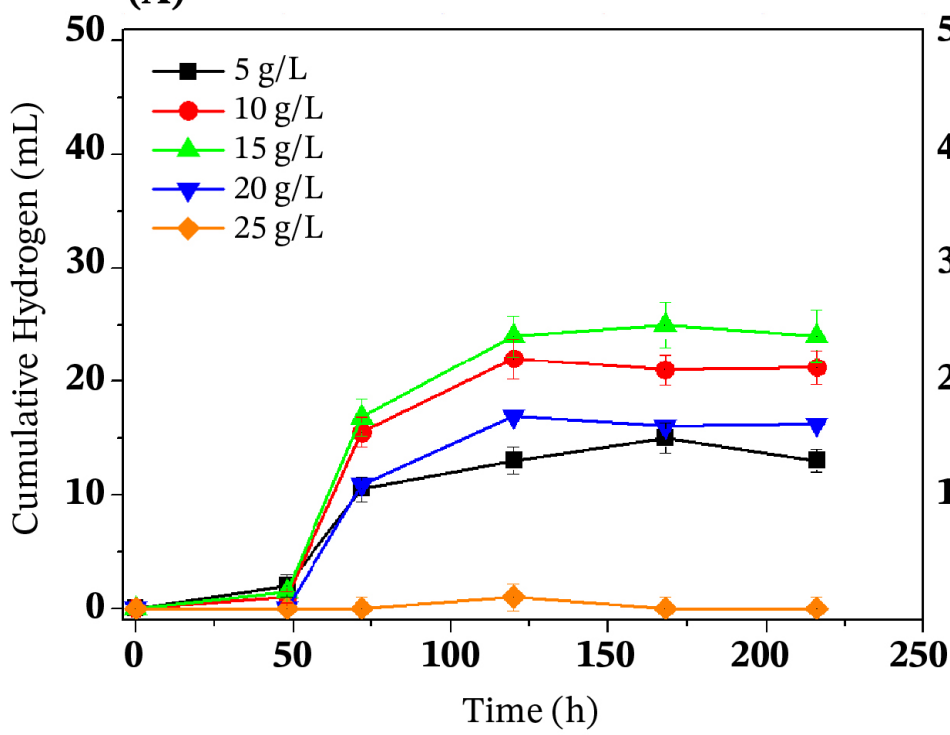

(B)

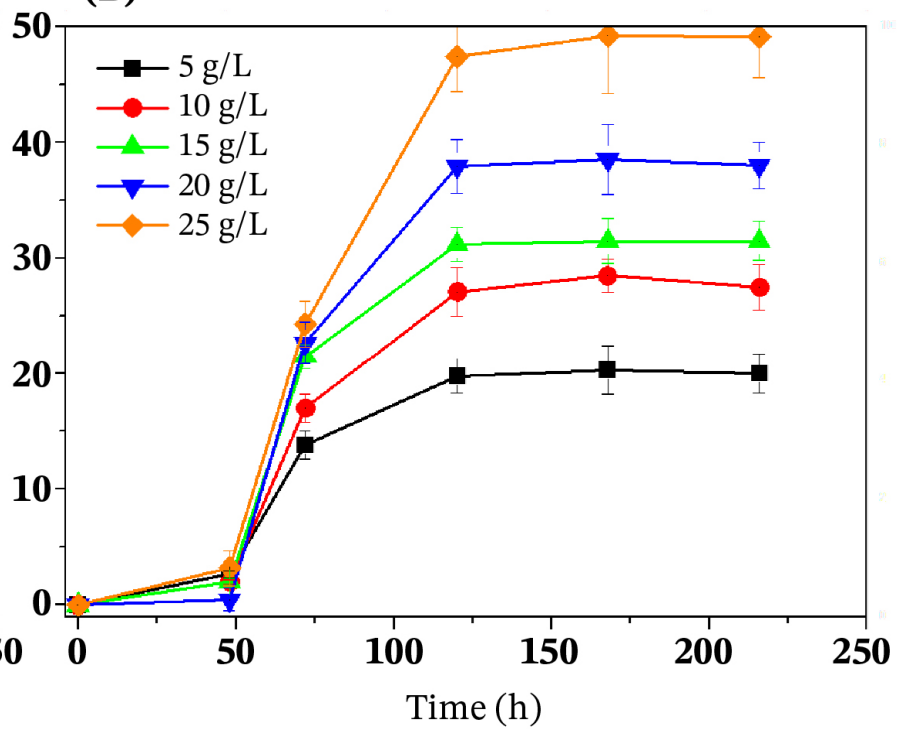

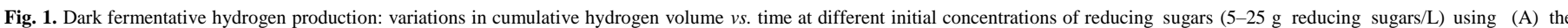
untreated and (B) the mild heat-pretreated substrate.

Table 2.

Effect of mild heat pretreatment of the substrate on biohydrogen production.

\begin{tabular}{|c|c|c|c|c|c|c|c|c|c|c|}
\hline \multirow{2}{*}{ Substrate } & \multirow{2}{*}{$\begin{array}{l}\text { Initial reducing } \\
\text { sugars }(\mathrm{g} / \mathrm{L})\end{array}$} & \multirow{2}{*}{ Final pH } & \multirow{2}{*}{$\begin{array}{c}\text { BOD }_{5} \text { removal } \\
(\%)\end{array}$} & \multicolumn{3}{|c|}{ Gompertz parameters } & \multirow{2}{*}{$\begin{array}{c}\mathrm{H}_{2} \\
(\%)\end{array}$} & \multirow{2}{*}{$\begin{array}{c}\mathbf{H}_{2} \\
(\mathbf{m L} / \mathrm{L})\end{array}$} & \multirow{2}{*}{$\begin{array}{c}\text { VHPR } \\
(\mathrm{mL} / \mathrm{L} / \mathrm{d})\end{array}$} & \multirow{2}{*}{$\begin{array}{c}\mathbf{H}_{2} \text { yield } \\
(\mathrm{mL} / \mathrm{g} \text { VS) }\end{array}$} \\
\hline & & & & $\underset{(\mathrm{mL})}{\mathrm{H}_{\max }}$ * & $\begin{array}{c}\mathbf{R}_{\max } \\
(\mathbf{m L} / \mathbf{h})\end{array}$ & $\begin{array}{c}\lambda \\
(\mathbf{h})\end{array}$ & & & & \\
\hline \multirow{5}{*}{ Untreated } & 5 & 5.2 & 22 & 13.5 & 0.3 & 33 & 21 & 169 & 88.3 & 86.6 \\
\hline & 10 & 5.0 & 24 & 21.5 & 0.4 & 33 & 28 & 269 & 128.5 & 68.8 \\
\hline & 15 & 5.0 & 30 & 24.0 & 0.5 & 35 & 30 & 300 & 143.7 & 51.1 \\
\hline & 20 & 4.7 & 12 & 16.3 & 0.3 & 43 & 23 & 204 & 102.0 & 26.1 \\
\hline & 25 & 4.0 & 7 & 0 & 0 & --- & 0 & 0 & 0 & 0 \\
\hline \multirow{5}{*}{$\begin{array}{l}\text { Mild heat- } \\
\text { pretreated }\end{array}$} & 5 & 5.0 & 29 & 20.2 & 0.5 & 42 & 31 & 252 & 146.5 & 129.2 \\
\hline & 10 & 5.0 & 35 & 28.0 & 0.6 & 44 & 35 & 350 & 184.7 & 89.5 \\
\hline & 15 & 4.8 & 43 & 31.5 & 0.9 & 46 & 39 & 394 & 265.7 & 67.2 \\
\hline & 20 & 4.6 & 45 & 38.3 & 1.0 & 49 & 42 & 478 & 300.3 & 61.2 \\
\hline & 25 & 4.6 & 50 & 49.2 & 1.2 & 55 & 46 & 615 & 372.6 & 63.0 \\
\hline
\end{tabular}

* $\mathrm{H}_{\text {max }}$ : peak hydrogen production; $\mathrm{R}_{\max }$ : hydrogen production rate; $\lambda$ : lag time; VHPR: volumetric hydrogen production rate.

producing bacteria in the inoculum required a longer adaptation time. In spite of that, the highest $\mathrm{H}_{\max }$ and $\mathrm{R}_{\max }$ values corresponded to the longest $\lambda$.

In addition, as shown in Table 2 , mild heat pretreatment significantly enhanced the biohydrogen production performance at all substrate concentrations. The hydrogen yield was increased to $129.2 \mathrm{~mL} / \mathrm{g}$ VS when the FVW substrate was pretreated $v s$. the untreated substrate, corresponding to a $50 \%$ higher yield. The same behavior was also observed for the VHPR where its maximum value was raised in response to the application of the mild heat pretreatment to $372.6 \mathrm{~mL} / \mathrm{L} / \mathrm{d}$ at $25 \mathrm{~g} / \mathrm{L}$, corresponding to a $160 \%$ enhancement $v s$. the untreated substrate (substrate concentration $=15 \mathrm{~g} / \mathrm{L}$ ). Since VHPR is attribute to the inoculum capacity for biohydrogen production (Chen et al., 2002), the different VHPR values obtained for two tested systems would suggest the involvement of different microorganisms in the fermentation process. In another words, these findings confirmed that the process carried out with the mild heat-pretreated substrate benefited a more efficient microbial population.

Within a suitable range, increasing the reducing sugars content of the substrate improved the bioprocess. The results obtained herein were in agreement with those reported by other researchers indicating the correlation between the biogas and biohydrogen production and the carbohydrate content of the substrate used (Alibardi and Cossu, 2016). In this context, previous studies on batch production of biohydrogen have proved that the substrate/inoculum ratio (S/I) influenced the efficiency of the fermentative process and, contrary to what observed for methane yields, efficient hydrogen production were strictly related to high S/I ratios (Pan et al., 2008; Nathao et al., 2013).

Table 3 compares the hydrogen production values achieved in this study with those reported previously. The differences observed could be generally ascribed to the different characteristics of the wastes used caused by different sources, processing and handling methods, food habits, culture, and seasons (Xu et al., 2018). Nevertheless, it be comprehended that the bioprocess developed in the present study was superior further highlighting the significant contribution of mild heat pretreatment of the substrate to biohydrogen production. Thus, the use of pretreated FVW substrate at the highest initial concentration tested led to the highest hydrogen content $(46 \%$ 
Table 3.

Comparison of the results of different studies on batch biohydrogen production from different organic wastes containing fruit and vegetable.

\begin{tabular}{|c|c|c|c|c|c|c|c|}
\hline Substrate & Inoculum & $\mathbf{T}\left({ }^{\circ} \mathbf{C}\right)$ & pH & $\mathrm{H}_{2}$ production & $\mathrm{H}_{2}(\%)$ & SDE* & Reference \\
\hline Leaf-shaped vegetables waste & No inoculum & 28 & 6.8 & $24 \mathrm{~mL} / \mathrm{g}$ VS & 28 & NR & Marone et al. (2014) \\
\hline $\begin{array}{l}\text { Leaf-shaped vegetables waste }+ \\
\text { potato peels }\end{array}$ & No inoculum & 37 & 6.8 & $19 \mathrm{~mL} / \mathrm{g}$ VS & 32 & NR & Marone et al. (2014) \\
\hline Leaf-shaped vegetables kitchen waste & Kitchen waste compost & 55 & 6.0 & $11 \mathrm{~mL} / \mathrm{g} \mathrm{COD}^{\mathrm{c}}$ & 40 & $27.4 \%$ carbohydrate & Lee et al. (2008) \\
\hline Vegetable market waste & $\begin{array}{l}\text { Acid enriched anaerobic } \\
\text { sludge }\end{array}$ & 32 & $6.0^{\mathrm{b}}$ & $89 \mathrm{~mL} / \mathrm{g}$ COD & NR & $65 \% \mathrm{COD}$ & Venkata Mohan et al. (2009) \\
\hline Vegetable waste & Heat pretreated cow dung & 37 & $\mathrm{NC}$ & $4.9 \mathrm{~mL} / \mathrm{g} \mathrm{VS}$ & 98.8 & $81.3 \% \mathrm{COD}$ & Bansal et al. (2013) \\
\hline Food waste & Anaerobic sludge & 50 & $\mathrm{NC}$ & $57 \mathrm{~mL} / \mathrm{g}$ VS & 37 & $39 \% \mathrm{VS}$ & Pan et al. (2008) \\
\hline Food waste & Anaerobic sludge & 35 & NC & $39 \mathrm{~mL} / \mathrm{g}$ VS & 35 & $46 \% \mathrm{VS}$ & Pan et al. (2008) \\
\hline FVW & Anaerobic sludge & 55 & $7.0^{\mathrm{b}}$ & $76 \mathrm{~mL} / \mathrm{g} \mathrm{VS}$ & 28 & $70-78 \%$ COD & Keskin et al. (2018) \\
\hline Autoclaved FVW & Anaerobic sludge & 55 & $5.5-6.75$ & $27.19 \mathrm{~mL} / \mathrm{g} \mathrm{VS}$ & 41 & NR & Abubackar et al. (2019) \\
\hline Mild heat-pretreated FVW; $5 \mathrm{~g} / \mathrm{L}^{\mathrm{a}}$ & Vermicompost & 35 & $5.5^{\mathrm{b}}$ & $129.2 \mathrm{~mL} / \mathrm{g} \mathrm{VS}$ & 31 & $29 \% \mathrm{BOD}_{5}$ & This work \\
\hline Mild heat-pretreated FVW; $25 \mathrm{~g} / \mathrm{L}^{\mathrm{a}}$ & Vermicompost & 35 & $5.5^{\mathrm{b}}$ & $63.0 \mathrm{~mL} / \mathrm{g} \mathrm{VS}$ & 46 & $50 \% \mathrm{BOD}_{5}$ & This work \\
\hline
\end{tabular}

*SDE: substrate degradation efficiency; NR: not reported; NC: non control.

${ }^{a}$ Initial concentration of reducing sugars in substrate.

${ }^{\mathrm{b}}$ Initial level.

${ }^{\mathrm{c}}$ Calculated from data provided in the manuscript.

$\mathrm{v} / \mathrm{v}, 63.0 \mathrm{~mL} / \mathrm{g} \mathrm{VS}$ ) in the biogas together with the highest efficiency of substrate degradation $\left(50 \% \mathrm{BOD}_{5}\right)$.

While hydrogen production was lower $(63 \mathrm{~mL} / \mathrm{g}$ VS) at reducing sugars concentration of $25 \mathrm{~g} / \mathrm{L}$ than at $5 \mathrm{~g} / \mathrm{L}(129.2 \mathrm{~mL} / \mathrm{g} \mathrm{VS})$, it should be noted that water consumption for substrate dilution was also minimal under this condition. Moreover, the hydrogen production of $63 \mathrm{~mL} / \mathrm{g}$ VS was still higher than almost all the previously reported records under mesophilic conditions (Pan et al., 2008; Bansal et al., 2013; Marone et al., 2014). Keskin et al. (2018) obtained a $16 \%$ higher hydrogen yield than the value obtained in the present work but they operated the bioreactor under thermophilic conditions $\left(55^{\circ} \mathrm{C}\right)$. It should also be noted that biohydrogen production at lower temperatures (such as $35^{\circ} \mathrm{C}$ in the present investigation) corresponds to significant reductions in energy consumption.

The hydrogen generation recorded herein was 2.3 times higher than those recently reported by Abubackar et al. (2019), who also used a heat pretreated FVW substrate but under more severe thermal conditions (autoclaving). Although they used dry fermentation conditions arguing a lower water consumption and the absence of agitation in their bioprocess, the wet fermentation batches $(<10 \%$ solids) operated in this work presents several advantages in addition to the increased hydrogen yield. Those include milder substrate pretreatment conditions $\left(63{ }^{\circ} \mathrm{C} v s .120{ }^{\circ} \mathrm{C}\right)$, lower temperature of fermentation broth $\left(35^{\circ} \mathrm{C} v\right.$ s. $\left.55^{\circ} \mathrm{C}\right)$, and no use of chemical additives for $\mathrm{pH}$ control.

\subsection{Substrate degradation}

The variation in reducing sugars concentration was monitored through the course of the experiments to evaluate its impacts on both hydrogen production and substrate degradation. The degradation efficiency of reducing sugars was over $95 \%$ in all the assays conducted (data not showed). Moreover, the utilization of the biodegradable organic matter (measured as $\mathrm{BOD}_{5}$ reduction) in the batch reactors was evidenced, indicating the progress of the bioprocess (Náthia-Neves et al., 2018). BOD 5 removal efficiency varied between $7 \%$ and $30 \%$ in the experiments performed with the untreated substrate; while it was higher varying from $29 \%$ to $50 \%$ with increasing substrate concentration in the dark fermentation processes using the mild heat-pretreated substrate (see Table 2). Comparing the dark fermentation batches that produced the highest hydrogen content using the untreated and pretreated substrate $(15 \mathrm{~g} / \mathrm{L}$ and 25 $\mathrm{g} / \mathrm{L}$ of initial reducing sugars, respectively), it is important to point out that the maximum efficiency of the $\mathrm{BOD}_{5}$ removal increased by about $67 \%$ in response to the mild heat pretreatment of the FVW substrate.
As can be seen in Table 3, the substrate degradation efficiency values in the literature are presented in different units such as \% carbohydrate, $\%$ $\mathrm{COD}, \% \mathrm{VS}, \% \mathrm{BOD}_{5}$, and therefore no direct comparison would be possible.

\subsection{Soluble metabolites production and microbial community}

Hydrogen formation can be accompanied by the generation of VFA and other low-molecular weight products (Silva et al., 2018). Their distribution depends on the experimental conditions and the microorganisms involved in the bioprocess (Bansal et al., 2013). In this work, the metabolites formed during the dark fermentation process were analyzed to investigate their effects on biohydrogen production. Figure 2 shows the concentration of VFA and alcohols produced during the dark fermentation process, indicating that the mild heat pretreatment of the substrate had an enhancing impact on VFA production. The soluble metabolites produced were butyric acid, acetic acid, ethanol, and butanol. Among them, acetic acid was the main metabolite produced by the untreated substrate fermentation (76$91 \%$ ), while butyric acid was the main compound produced during the dark fermentation of the mild heat-pretreated substrate (71-81\%). In each batch reactor, the concentration of the main metabolites produced increased in response to increases in the initial concentration of reducing sugars within the tested range, with the VFA concentration recorded higher than the alcohol concentration. Thus, the formation of the majority of these compounds led to the acidification of the fermentation broth. In addition, and under the experimental conditions used herein, the liquid phase contained no propionic acid, which is of relevance, given the fact that this organic acid may repress the activity of hydrogen-producing bacteria and reduce hydrogen yield (Venkata Mohan et al., 2009; Bundhoo and Mohee, 2016).

In the experiments carried out with the mild heat-pretreated FVW substrate, a higher amount of butyric acid was generated compared to acetic acid, resulting in a more favorable microenvironment for the acidogenic activity. In general, biohydrogen formation and VHPR were increased significantly when the butyric acid concentration was higher. These results were in agreement with those reported by Bansal et al. (2013), who showed that hydrogen production with anaerobic bacteria proceeded generally via butyrate-type fermentation. Taking into account that Clostridium species are expected to be the dominant microorganisms in the batch reactors (Blomström et al., 2016), they would be responsible for butyrate-type fermentation (Chen et al., 2002; Kim et al., 2013). Moreover, other 


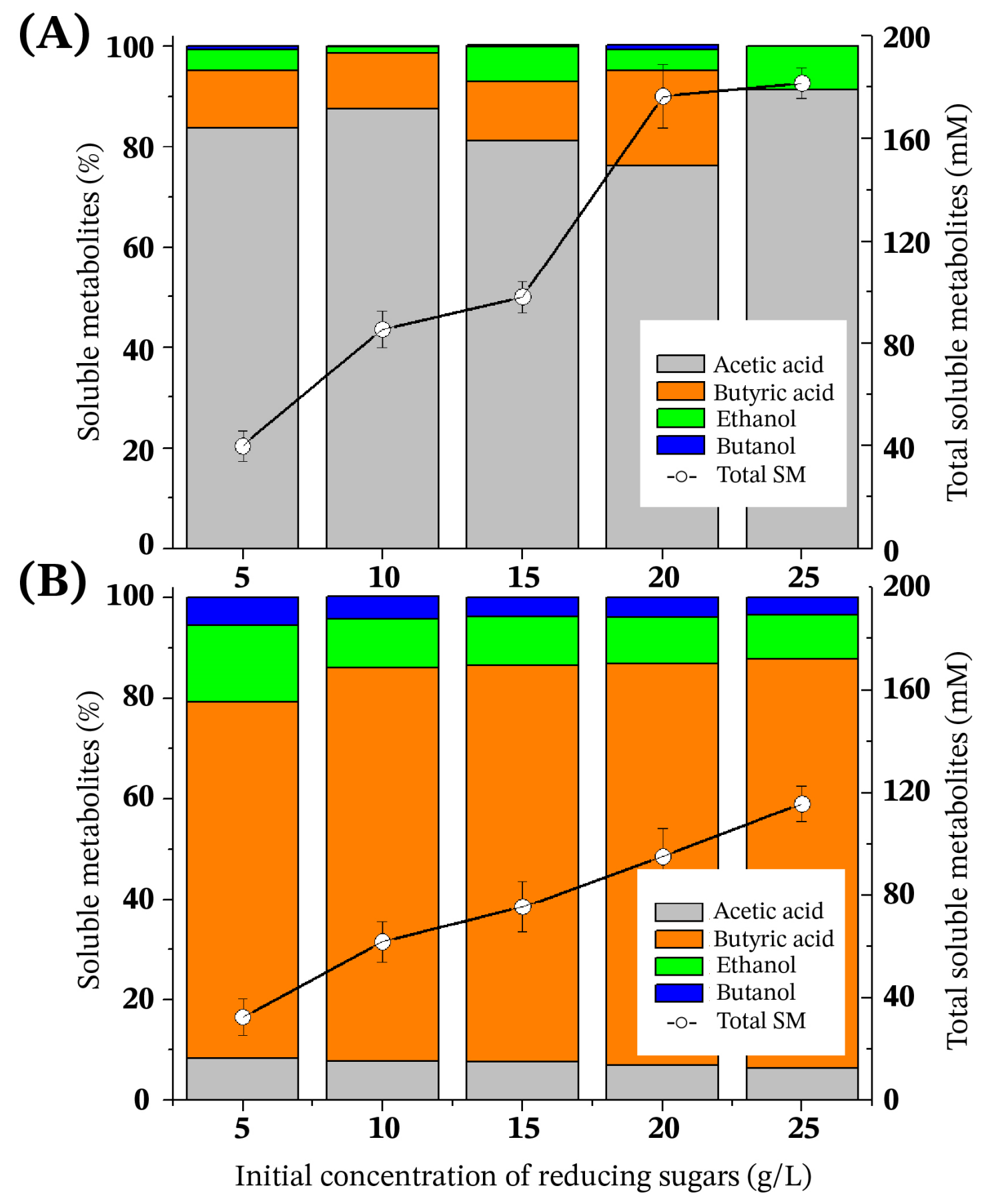

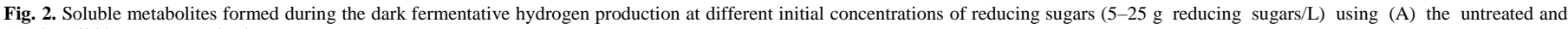
(B) the mild heat-pretreated substrate.

researchers have reported that the presence of ethanol and butanol correlates with the metabolic activity of Clostridium sp. (Silva et al., 2018). This could also be confirmed based on the results obtained in the microbiological assays performed on samples of inoculum, substrate, and dark fermentation broth (for substrates concentrations which produced the highest hydrogen contents) (Table 4). Thus, bacterial species associated with the genus Clostridium $(5.1 \times$ $10^{5} \mathrm{MPN} / 100 \mathrm{~mL}$ ) were the main microorganisms identified and quantified in the dark fermentation broths containing the mild heat-pretreated FVW substrate. This finding revealed that vermicompost was an excellent and economical source of enrichment for hydrogen-producing bacteria and resulted in efficient fermentation of the substrate rich in reducing sugars to biohydrogen.

The distribution of soluble acid metabolites in the experiments conducted using the untreated FVW could be attributed to the presence of Enterobacter species in the substrate (Table 4). In this scenario, these bacteria could compete with the inoculated microorganisms (Clostridium 
Table 4.

Microbiological analysis of the raw materials and fermentation batch reactors

\begin{tabular}{|c|c|c|c|c|c|}
\hline \multirow{2}{*}{ Microorganisms (MPN/100 mL) } & \multirow{2}{*}{ Inoculum } & \multicolumn{2}{|c|}{ Substrate } & \multicolumn{2}{|c|}{ Fermentation broth } \\
\hline & & Untreated & Mild heat-pretreated & US15 & PS25 \\
\hline Clostridium spp. & $2.2 \times 10^{5}$ & Negative & Negative & $5.1 \times 10^{3}$ & $5.1 \times 10^{5}$ \\
\hline Enterobacter spp. & Negative & $9.2 \times 10^{4}$ & Negative & $1.6 \times 10^{4}$ & Negative \\
\hline
\end{tabular}

US15: fermentation broth with untreated substrate (15 g reducing sugars/L); PS25: fermentation broth with pretreated substrate (25 g reducing sugars/L).

spp.) and generate high amounts of acetic acid resulting in a marked $\mathrm{pH}$ decrease, which could consequently reduce the efficiency of the fermentation process (Wang and Yin, 2017). In this context, it could be concluded from Figures 1 and 2 that the highest concentration of this organic acid was related to the lowest biohydrogen production. Thus, increasing concentrations of the untreated substrate must have provided larger populations of natural microorganisms impeding the biohydrogen production process while this challenge was effectively overcome through the implementation of the mild heat pretreatment of FVW, eliminating the competing microbial populations in favor of the hydrogen-producing bacteria.

\section{Conclusions}

In this work, vermicompost as economical source of hydrogen-producing bacteria and FVW as a low-cost substrate were innovatively combined for biohydrogen production. Effects of mild heat pretreatment of the substrate and its concentration on the bioprocess were studied. Comparatively, higher biohydrogen production $\left(63.0 \mathrm{~mL} / \mathrm{g}\right.$ VS) and $\mathrm{BOD}_{5}$ removal $(50 \%)$ were observed in the dark fermentative experiments performed with mild heatpretreated substrate. Substrate pretreatment improved the hydrogen production through the elimination of the natural microbiota present in the FVW which in turn provided a more favorable (competition-free) microenvironment for the inoculated microorganisms. The distribution of soluble metabolites suggested that the metabolic pathway leading to the formation of butyric acid was effective in the production of hydrogen gas. Clostridium species were the dominant organisms in the bioprocess. The results obtained herein could contribute to the knowledge applicable to both FVW recovery via biological treatment reducing the amount of wastes deposited in landfills, and the development of new technologies leading to biohydrogen generation as clean energy carrier.

\section{Acknowledgements}

The authors wish to acknowledge the financial support of CIQA-UTN from Córdoba, Argentina. MJP acknowledges the fellowship from UTN, Argentina. MBGC and PRD are members of Research Career of CONICET, Argentina.

\section{References}

[1] Abubackar, H.N., Keskin, T., Yazgin, O., Gunay, B., Arslan, K., Azbar, N., 2019. Biohydrogen production from autoclaved fruit and vegetable wastes by dry fermentation under thermophilic condition. Int. J. Hydrogen Energy. 44(34), 18776-18784

[2] Algapani, D.E., Wei, Q., Min, S., di Pumpo, F., Wandera, S.M., Adani, F., Dong, R., 2016. Bio-hydrolysis and bio-hydrogen production from food waste by thermophilic and hyperthermophilic anaerobic process. Bioresour. Technol. 216, 768-777.

[3] Alibardi, L., Cossu, R., 2016. Effects of carbohydrate, protein and lipid content of organic waste on hydrogen production and fermentation products. Waste Manage. 47, 69-77.

[4] APHA, 2012. Standard methods for the examination of water and wastewater. 22nd ed. American Public Health Association, Washington,
[5] Arimi, M.M., Knodel, J., Kiprop, A., Namango, S.S., Zhang, Y., Geißen, S.U., 2015. Strategies for improvement of biohydrogen production from organic-rich wastewater: a review. Biomass Bioenergy. 75, 101-118.

[6] Bakonyi, P., Borza, B., Orlovits, K., Simon, V., Nemestóthy, N., Bélafi-Bakó, K., 2014. Fermentative hydrogen production by conventionally and unconventionally heat pretreated seed cultures: a comparative assessment. Int. J. Hydrogen Energy. 39(11), 55895596.

[7] Bansal, S.K., Sreekrishnan, T.R., Singh, R., 2013. Effect of heat pretreated consortia on fermentative biohydrogen production from vegetable waste. National Acad. Sci. Lett. 36(2), 125-131.

[8] Blomström, A.L., Lalander, C., Komakech, A.J., Vinnerås, B. Boqvist, S., 2016. A metagenomic analysis displays the diverse microbial community of a vermicomposting system in Uganda. Infect. Ecol. Epidemiol. 6(1), 32453.

[9] Bo, W., Yongye, L., Yahua, Q., Yang, Y., Qiang, S., Wei, W. Jianlong, W., 2012. Technology research on bio-hydrogen production. Procedia Eng. 43, 53-58.

[10] Braguglia, C.M., Gallipoli, A., Gianico, A., Pagliaccia, P., 2018. Anaerobic bioconversion of food waste into energy: a critical review. Bioresour. Technol. 248, 37-56.

[11] Bundhoo, M.Z., Mohee, R., Hassan, M.A., 2015. Effects of pretreatment technologies on dark fermentative biohydrogen production: a review. J. Environ. Manage. 157, 20-48.

[12] Bundhoo, M.Z., Mohee, R., 2016. Inhibition of dark fermentative bio-hydrogen production: a review. Int. J. Hydrogen Energy. 41(16), 6713-6733.

[13] Cai, J., Wang, G., 2016. Comparison of different pre-treatment methods for enriching hydrogen-producing bacteria from intertidal sludge. Int. J. Green Energy. 13(3), 292-297.

[14] Chen, C.C., Lin, C.Y., Lin, M.C., 2002. Acid-base enrichment enhances anaerobic hydrogen production process. Appl. Microbiol. Biotechnol. 58(2), 224-228.

[15] Cruwys, J.A., Dinsdale, R.M., Hawkes, F.R., Hawkes, D.L., 2002 Development of a static headspace gas chromatographic procedure for the routine analysis of volatile fatty acids in wastewaters. J. Chromatogr. A. 945(1-2), 195-209.

[16] Cruz-Salomón, A., Ríos-Valdovinos, E., Pola-Albores, F., MezaGordillo, R., Lagunas-Rivera, S., Ruíz-Valdiviezo, V.M., 2017. Anaerobic treatment of agro-industrial wastewaters for COD removal in expanded granular sludge bed bioreactor. Biofuel Res. J. $16,715-720$

[17] Cui, M., Shen, J., 2012. Effects of acid and alkaline pretreatments on the biohydrogen production from grass by anaerobic dark fermentation. Int. J. Hydrogen Energy. 37(1), 1120-1124.

[18] Domínguez, J., Aira, M., Gómez-Brandón, M., 2010. Vermicomposting: earthworms enhance the work of microbes, in: Insam, H., Franke-Whittle, I., Goberna, M. (Eds.), Microbes at Work. Springer-Verlag Berlin Heidelberg, Heidelberg, pp. 93-114.

[19] Eker, S., Sarp, M., 2017. Hydrogen gas production from waste paper by dark fermentation: effects of initial substrate and biomass concentrations. Int. J. Hydrogen Energy. 42(4), 2562-2568. 
[20] Elbeshbishy, E., Dhar, B.R., Nakhla, G., Lee, H.S., 2017. A critical review on inhibition of dark biohydrogen fermentation. Renew. Sustain. Energy Rev. 79, 656-668.

[21] Emodi, N.V., Chaiechi, T., Beg, A.R.A., 2019. A techno-economic and environmental assessment of long-term energy policies and climate variability impact on the energy system. Energy Policy. 128, 329-346.

[22] FAO, 2011. Global food losses and food waste - Extent, causes and prevention. SAVE FOOD: An initiative on Food Loss and Waste Reduction. Rome.

[23] Ghimire, A., Frunzo, L., Pirozzi, F., Trably, E., Escudie, R., Lens, P.N. Esposito, G., 2015. A review on dark fermentative biohydrogen production from organic biomass: process parameters and use of byproducts. Appl. Energy. 144, 73-95.

[24] Gómez-Brandón, M., Domínguez, J., 2014. Recycling of solid organic wastes through vermicomposting: microbial community changes throughout the process and use of vermicompost as a soil amendment. Crit. Rev. Environ. Sci. Technol. 44(12), 1289-1312.

[25] Hallenbeck, P.C., Ghosh, D., 2009. Advances in fermentative biohydrogen production: the way forward. Trends Biotechnol. 27(5), 287-297.

[26] Hong, S.W., Lee, J.S., Chung, K.S., 2011. Effect of enzyme producing microorganisms on the biomass of epigeic earthworms (Eisenia fetida) in vermicompost. Bioresour. Technol. 102(10), 6344-6347.

[27] International Standard Organization, ISO., 1986. ISO 6461/1 Water quality: detection and enumeration of the spores of sulphite-reducing anaerobes (Clostridia).

[28] Keskin, T., Arslan, K., Abubackar, H.N., Vural, C., Eroglu, D., Karaalp, D., Yanik, J., Ozdemir, G., Azbar, N., 2018. Determining the effect of trace elements on biohydrogen production from fruit and vegetable wastes. Int. J. Hydrogen Energy. 43(23), 10666-10677.

[29] Kim, S., Choi, K., Kim, J.O., Chung, J., 2013. Biological hydrogen production by anaerobic digestion of food waste and sewage sludge treated using various pretreatment technologies. Biodegradation. 24(6), 753-764.

[30] Lee, Z.K., Li, S.L., Lin, J.S., Wang, Y.H., Kuo, P.C., Cheng, S.S., 2008. Effect of $\mathrm{pH}$ in fermentation of vegetable kitchen wastes on hydrogen production under a thermophilic condition. Int. J. Hydrogen Energy. $33(19), 5234-5241$

[31] Li, C., Fang, H.H.P., 2007. Fermentative hydrogen production from wastewater and solid wastes by mixed cultures. Crit. Rev. Environ. Sci. Technol. 37(1), 1-39.

[32] Lin, P.Y., Whang, L.M., Wu, Y.R., Ren, W.J., Hsiao, C.J., Li, S.L., Chang, J.S., 2007. Biological hydrogen production of the genus Clostridium: metabolic study and mathematical model simulation. Int. J. Hydrogen Energy. 32(12), 1728-17535.

[33] Marone, A., Izzo, G., Mentuccia, L., Massini, G., Paganin, P., Rosa, S., Varrone, C., Signorini, A., 2014. Vegetable waste as substrate and source of suitable microflora for bio-hydrogen production. Renewable Energy. 68, 6-13.

[34] Miller, G.L., 1959. Use of dinitrosalicylic acid reagent for determination of reducing sugar. Anal. Chem. 31(3), 426-428.

[35] Nathao, C., Sirisukpoka, U., Pisutpaisal, N., 2013. Production of hydrogen and methane by one and two stage fermentation of food waste. Int. J. Hydrogen Energy. 38(35), 15764-15769.
[36] Náthia-Neves, G., Neves, T.D.A., Berni, M., Dragone, G. Mussatto, S.I., Forster-Carneiro, T., 2018. Start-up phase of a twostage anaerobic co-digestion process: hydrogen and methane production from food waste and vinasse from ethanol industry. Biofuel Res. J. 5(2), 813-820.

[37] Oceguera-Contreras, E., Aguilar-Juárez, O., Oseguera-Galindo, D., Macías-Barragán, J., Bolaños-Rosales, R., Mena-Enríquez, M. Arias-García, A., Montoya-Buelna, M., Graciano-Machuca, O., De León-Rodríguez, A., 2019. Biohydrogen production by vermihumus-associated microorganisms using agro industria wastes as substrate. Int. J. Hydrogen Energy. 44(20), 9856-9865.

[38] Owen, W.F., Stuckey, D.C., Healy Jr, J.B., Young, L.Y., McCarty, P.L., 1979. Bioassay for monitoring biochemical methane potentia and anaerobic toxicity. Water Res. 13(6), 485-492.

[39] Pan, J., Zhang, R., El-Mashad, H.M., Sun, H., Ying, Y., 2008. Effect of food to microorganism ratio on biohydrogen production from food waste via anaerobic fermentation. Int. J. Hydrogen Energy. 33(23), 6968-6975

[40] Rafieenia, R., Lavagnolo, M.C., Pivato, A., 2018. Pre-treatment technologies for dark fermentative hydrogen production: Current advances and future directions. Waste Manage. 71, 734-748.

[41] Saady, N.M.C., 2013. Homoacetogenesis during hydrogen production by mixed cultures dark fermentation: unresolved challenge. Int. J. Hydrogen Energy. 38(30), 13172-13191.

[42] Salem, A.H., Brunstermann, R., Mietzel, T., Widmann, R., 2018. Effect of pre-treatment and hydraulic retention time on biohydrogen production from organic wastes. Int. J. Hydrogen Energy. 43(10), 4856-4865

[43] Shahriari, H., Warith, M., Hamoda, M., Kennedy, K.J., 2012. Anaerobic digestion of organic fraction of municipal solid waste combining two pretreatment modalities, high temperature microwave and hydrogen peroxide. Waste Manag. 32(1), 41-52.

[44] Silva, J.S., Mendes, J.S., Correia, J.A.C., Rocha, M.V.P., Micoli, L., 2018. Cashew apple bagasse as new feedstock for the hydrogen production using dark fermentation process. J. Biotechnol. 286, 7178

[45] Tawfik, A., El-Qelish, M., Salem, A., 2015. Efficient anaerobic codigestion of municipal food waste and kitchen wastewater for biohydrogen production. Int. J. Green Energy. 12(12), 1301-1308.

[46] Venkata Mohan, S., Mohanakrishna, G., Kannaiah Goud, R. Sarma, P.N., 2009. Acidogenic fermentation of vegetable based market waste to harness biohydrogen with simultaneous stabilization. Bioresour. Technol. 100(12), 3061-3068.

[47] Wang, J., Yin, Y., 2017. Biohydrogen production from organic wastes. Green Energy and Technology. Springer Nature, Singapore.

[48] Wang, J., Yin, Y., 2018. Fermentative hydrogen production using various biomass-based materials as feedstock. Renew. Sust. Energy Rev. 92, 284-306.

[49] Xia, A., Jacob, A., Herrmann, C., Murphy, J.D., 2016. Fermentative bio-hydrogen production from galactose. Energy. 96, 346-354.

[50] Xu, F., Li, Y., Ge, X., Yang, L., Li, Y., 2018. Anaerobic digestion of food waste-challenges and opportunities. Bioresour. Technol. 247, 1047-1058. 